УДК 330.12.

DOI: $10.25198 / 2077-7175-2020-5-52$

\title{
RUSSIAN ENTREPRENEURS HISTORICAL MINDSET IN EXAMPLIFICATION OF FUTURE ECONOMISTS MORAL CHARACTER SHAPING
}

\author{
A. B. Ilin \\ Bauman Moscow State Technical University, Moscow, Russia \\ email: ilandeducation@yandex.ru

\section{Yu. S. Sizova} \\ Plekhanov Russian University of Economics, Moscow, Russia \\ email: Sizova.YS@rea.ru, ju-si@mail.ru
}

Abstract. The paper focuses on the moral portrait of modern Russian entrepreneurs which is currently subject to a drastic change. A historical overview of Russian entrepreneurial traditions is provided. Entrepreneur moral has always played a vital role in economy development and will always play. Moreover, business people values affect the institutional interaction at micro-, mezo- and macro-levels.

To highlight the entrepreneurial culture principles of Russian entrepreneurs from historical point of view, and show illiteracy of modern students in economics in the issues of Russian entrepreneurship history.

Methods and methodological units of research are content analysis, culture genesis, empirical study.

The poll of the first and second-year students of two leading universities was conducted, and its results revealed ignorance of to-be economists on the issues of Russian entrepreneurship history. Hence, our students would not be able to follow the traditions of Russian entrepreneurship.

The scientific novelty of the study lies in the theoretical and methodological justification of moral qualities of Russian entrepreneurs of the $19^{\text {th }}-20^{\text {th }}$ centuries and their applicability/impossibility of use by modern entrepreneurs in conditions of informatization and digitalization.

Research results can be used by Universities for tailoring their educational programmes for to-be economists and entrepreneurs.

Key words: entrepreneurship, business, education, history, economics, moral qualities.

Cite as: Ilin, A. B., Sizova, Yu. S. (2020) [Russian entrepreneurs historical mindset in examplification of future economists moral character shaping]. Intellekt. Innovatsii. Investitsii [Intellect. Innovations. Investments]. Vol. 5, pp. 52-58. DOI: $10.25198 / 2077-7175-2020-5-52$.

\section{ИСТОРИЧЕСКАЯ ИДЕОЛОГИЯ РОССИЙСКИХ ПРЕДПРИНИМАТЕЛЕЙ КАК ПРИМЕР ДЛЯ ФОРМИРОВАНИЯ МОРАЛЬНЫХ ЦЕННОСТЕЙ БУДУЩИХ ЭКОНОМИСТОВ}

\author{
А. Б. Ильин \\ Московский государственный технический университет имени Н. Э. Баумана, Москва, Россия \\ e-mail: ilandeducation@yandex.ru
}

\section{Ю. С. Сизова}

Российский экономический университет имени Г. В. Плеханова, Москва, Россия e-mail: Sizova.YS@rea.ru

\footnotetext{
Аннотация. Работа фокусируется на нравственном портрете современных российских предпринимателей, который в настоящее время подвергается резким изменениям. Представлен исторический обзор российских предпринимательских традиций. Моральный кодекс предпринимателя всегда играл жизненно важную роль в развитии экономики и всегда будет иметь значение. Кроме того, иенности деловых людей влияют на институциональное взаимодействие на микро-, мезо- и макроуровне.

Цель статьи - осветить принципь предпринимательской культуры российских предпринимателей с исторической точки зрения, показать безграмотность современных студентов экономических спеичиальностей в вопросах истории российского предпринимательства.

Методами и методологическим аппаратом исследования послужили контент-анализ, культурогенез, эмпирическое исследование.
} 
Проведен опрос студентов первого и второго курсов двух ведущих российских вузов, результаты которого выявили, что современные студенты экономических специальностей несведущи в вопросах истории российского предпринимательства. Таким образом, наши студенты не смогут следовать традициям российского предпринимательства.

Научная новизна исследования содержится в теоретическом и методологическом обосновании моральных качеств российских предпринимателей 19-20-х веков и их применимости/невозможности использования современными предпринимателями в условиях информатизации и циифровизации.

Результаты исследований могут использоваться высшими учебными заведениями для адаптаџии своих образовательных программ к интересам экономистов и предпринимателей.

Ключевые слова: предпринимательство, бизнес, образование, история, экономика, моральнье качества.

Для цитирования: Ilin, A. B., Sizova, Yu. S. (2020) [Russian entrepreneurs historical mindset in examplification of future economists moral character shaping]. Intellekt. Innovatsii. Investitsii [Intellect. Innovations. Investments]. Vol. 5, pp. 52-58. DOI: 10.25198/2077-7175-2020-5-52.

\section{Introduction}

All the changes taking place in Russia, economic, social, and political, contribute to the creation of a new business environment. This new environment is driven not only by global geopolitical and technological risks, but also by specific business conditions [12]. Despite the rapid development of society and technologies affecting the development of the entrepreneurial environment, the lessons of the past cannot be neglected.

History of Russia is closely interrelated with the history of national entrepreneurship. Entrepreneurs played an important role in the Russian economy development, new lands development, country's economic and military power strengthening, and the growth of its authority in the world.

The history of Russian entrepreneurship is of particular interest not only to historians and economists. The emergence, formation and development of Russian entrepreneurship in historical influenced the peculiarities of the economic activities of Russian entrepreneurs, their mentality, laid the ethical foundations of business relations, contributed to the emergence and development of social responsibility [14].

\section{Discussion}

If we trace the genesis of Russian statehood formation, we can state that Prince Oleg also carried out business communications with Constantinople, which at that time was the world capital. Russian merchants had a base point there. KievanRus and the polovtsy, the Russian principalities and the Bulgarian kingdom in the $11^{\text {th }}-13$ th centuries, are connected by intensive trade, which led to the development of commodity-money relations.

Russian entrepreneurs' moral qualities of the $9^{\text {th }}$ $15^{\text {th }}$ centuries: a combination of prudence and imagination, high working capacity and the ability to relax, the desire to be ourselves, the presence of deep and hard introspection; observation, sociability, courage, enterprise, responsibility for each other to counterparties.

The King Ivan Grozny promoted the Russian economy development of crafts and industries, encouraged economic advancement to the East. In particular, Yermak laid the foundation for Russia's advance into Siberia. In this historical period many landowners lived in subsistence farming, some created their own factories and engaged in trade. In industry, there is a transition to a method of production manufacturing. Thus, the $15^{\text {th }}-17^{\text {th }}$ century's Russian business turns into a clear, ramified rapidly developing system. It is also worth mentioning the occurrence of Russia manufactories and the development of small commodity production at that time.

Russian entrepreneurs' moral qualities of the $15^{\text {th }}$ $16^{\text {th }}$ centuries: a sense of proportion, practical calculation, self-control, sobriety of character, willpower [1].

Peter I took the first steps to establish joint-stock companies in Russia. The number of manufactories under the Russian state first emperor increased from 10 to 230. Whereas until Peter the Great, merchants became widespread in Russia, then during the Great Reformer a powerful incentive was given to the development of industry itself. During his reign, there was formed the following composition of entrepreneurial relations subjects: foreign merchants and industrialists, Russian merchants, state-owned «palace» entrepreneurs and monasteries.

The Empress Elizaveta Petrovna marks another turning-point in the history of Russian business development. She signed a decree of May 13, 1754, which approved the creation of the first Russian bank - the Noble borrowed bank. Prior to this, the main creditors were moneylenders, the largest of which were monasteries and merchants.

The Russian Empire's whole history is connected with entrepreneurs. It should be understood that Russian entrepreneurs were, are and remain different. At that time, the bulk of them were serfs. Their entrepreneurial function was to earn money for the landowner: they had to regularly give a certain amount to their master. To some extent, it was paying taxes. In 1861, after the serfdom was abolished, peasants signed up to the Russian economy. They created the foundations of Russian small and medium-sized enterprises [4]. How- 
ever, due to criticism of entrepreneurship, its secondary nature in the economy, most Russian entrepreneurs (immigrants from the peasant environment) were contemptuously called «grimy».

Russian entrepreneurs' moral qualities of the $16^{\text {th }}$ 17th centuries: initiative and energetic serfs. A peasant entrepreneur acted in unimaginably difficult conditions, only because of the firmness of his character and determination so many of them managed to overcome all the obstacles of their cramped state ${ }^{1}$.

Businessmen have almost always been associated with people who pursue only mercantile interests and have unattractive personal qualities in historical, philosophical, and fiction. Business is opposed to culture, and entrepreneurs themselves are people deprived of spiritual ideals, spiritually callous, uncultured and uneducated, dishonest and unceremonious. For example, in the play by A. N. Ostrovsky «Thunderstorm» entrepreneurs Kabanikha and Dikoy endowed with a mass of negative traits. They are tyranny, mock workers, mock the high feelings of relatives.

The notion that business was foreign to the Russian spirit and was introduced into Russian reality from abroad, or due to the activities of foreigners living in the Russian state, was rooted among Russian scientists, thinkers and writers. Russian carelessness and antienterprise opinion was expressed by many scientists. For example, D. I. Mendeleev, who was latch on to the Russian industry issues in the $19^{\text {th }}-20^{\text {th }}$ centuries, noted that a significant reason for the small development of industry in Russia should be the lack of personal enterprise, determined mainly by the fact that Russian people are used to getting everything ready, as a gift from anyone it was neither above or below, and if the manna of heaven does not fall from heaven by itself, then our education is used to blaming someone either from above or below, and it does not do anything if it involves personal labor, risk and perseverance, as it is necessary for the industry affairs [8].

Such a moral perception of entrepreneurship intensified in the $20^{\text {th }}$ century. Anti-entrepreneurial ideas formed in society during the period of socialist construction (1917-1980ss). Nevertheless, the so-called special exporters and special exporters operated in the framework of the country's foreign economic activity. These were state-owned enterprises that operated largely according to market laws, since their activities were carried out mainly on the world market. A number of enterprises constantly operated abroad (for example, Aeroflot competed with foreign airlines). History has not left examples that would testify to the lack of entrepreneurship among Russian people and the rejection by Russian people professional management of their own business [4].
The moral qualities of Russian entrepreneurs at the beginning of the 20 ${ }^{\text {th }}$ century: August Isaakovich Kaminka (1865-1941) believed that «an entrepreneur is a person who, in order to profit himself or herself through other persons, leads an enterprise at his own expense, and it can lead it alone or in connecting with others»). Therefore, an entrepreneur is a person who owns his own enterprise, finances it, manages it and has the main motive - making a profit [5]. Another pre-revolutionary Russian scientist Lev Iosifovich Petrazhitsky (18671931) argued that an entrepreneur should recognize a person who independently, personally and on his own behalf conducts business activities and bears the risk of all property and responsibility with all his property [9].

Entrepreneurship began to be perceived by the population as an acceptable and worthy area of professional activity, after the collapse of the Soviet Union. People started to gradually apprehend that to upgrade their standard of living, and to upgrade their quality of life, one should not rely on manna from heaven, and above all on their own strength (according to D. I. Mendeleev). A moral understanding was formed in society that the reluctance to independently build life plans could not be compensated by discussions about the mysterious Russian soul, which was not characteristic of the entrepreneurship beginnings, motives for doing business and mercantile calculation.

In some publications that became popular or written during the period of reforms in Russia (1990s and 2000s), one could read about:

- incompatibility of business and Russian national character;

- radical anti-bourgeoisness of the Russian Orthodox mentality;

- the rejection of market values by Russians;

- the absence of any Russian genetic predisposition to engage in entrepreneurship;

- $\quad$ artificial introduction of entrepreneurial ideas into the Russian environment by other peoples of Russia or from abroad.

Russian entrepreneurs' moral at the turn of the $20^{\text {th }}$ $21^{\text {st }}$ centuries: the economic structure remnants of the Soviet economy times, the oligarchic structure, ethnic and ethnic conflicts in business, criminalization, corrupt rents, competitiveness, investment, the creation of startups.

In the conditions of a market economy, new relations are being formed for all entities interacting with entrepreneurial activity. And although entrepreneurship has existed in the Russian Federation for a quarter century, in the general historical aspect, entrepreneurship in Russia has existed for more than 1150 years. The business composition entities in different periods of the Russian economy included: 
- $\quad$ serfs who are obliged to regularly pay in-kind or cash rent to the landlords;

- boyars, nobles, as well as other large and small landowners (landowners);

- monarchs (kings, grand dukes, specific princes, emperors and their families members);

independent city artisans and merchants from birth legal freedom;

Cossacks, including runaway peasants who lived on the outskirts of the country, from the time of the Wild Field, and created their own economic structure;

free producers - entrepreneurs (former serfs or ruined landowners,);

foreign nationals engaged in commercial or financial business or entrepreneurship in the territory of Russia;

criminals, thieves, robbers, hunting in the vast country ${ }^{2}$.

\section{Modern Students Knowledge about the History of Russian Entrepreneurship}

What do modern students really know about the history of Russian entrepreneurship? Can they name the large Russian entrepreneurs? What associations does «Russian merchant» evoke in them?

The survey results, conducted among junior students of such economic universities as the University of Synergy and the Russian Plekhanov University of Economics showed that out of all Russian entrepreneurs they know only Savva Morozov.

Some students mention the name of Mamontov, only in his material wealth context. Unfortunately such names of large Russian entrepreneurs as Kokorev, Gubonin, Ryabushinsky brothers, are unknown to modern young people. They are also not aware that historically the Russian businessmen were not indifferent to who and how made their fortune, but the pedigree of capital determined the rating of its owner in the Russian business environment [15], and the word «businessman» used to have an exclusively positive meaning - «doer of business», and only in Soviet times did it get a negative connotation, denoting a dishonest person who is engaged in fraud and who makes profit at the expense of the state and deceives him. But morality has been at the core of any Russian «business» from time immemorial. If we look at who was most respected in the Russian business environment even at the beginning of the 20th century, we will see that these were domestic producers, while financial speculators and moneylenders were the least. So Ryabushinsky V. P. noted that an industrialist (manufacturer) stood at the top of the pyramid in the Moscow unwritten merchant hierarchy, then came a merchant-trader, and below stood a man who gave money in growth, took into account bills, forced to work capital. He was not very respected, no matter how cheap his money was or how decent he was [10].

Buryshkin P. A. accented that a trading company, especially a large one, went into industry, at first it became commercial and industrial, and then completely abandoned trade, that means it sold only goods of its own product [2].

The goal of Russian entrepreneurship has never been to resell goods manufactured by someone and derive maximum profit from it, not to deceive the Russian state, but, to support it and strengthen its industry. But this is only one of the characteristic features of Russian entrepreneurship. According to the author of «Moscow Merchants», the attitude of entrepreneurs to their business was special in Russia, because they looked at their activity not so much as a source of income, but as a noble mission «assigned by God or fate» [2]. It was important how the entrepreneur made money. It was also important how he spent them, and business circles the saying "God blessed with wealth and will require a report on it» at one time was popular in Russian. They cannot fail to mention such names as Morozov, Bakhrushin, Tretyakov, Naydenov and Schukin. These figures not only invested their money (and souls too) in the development of Russian industry and trade, but actively participated in social and cultural-educational activities. The authors of this article adhere to the position that Russian entrepreneurship had a special culture, which, unfortunately, is not widely covered in the educational literature intended for students of economic universities and does not find a response in the public mind. Referring again to the history, we can see the Russian entrepreneur clearly realized that money is only a means, and the goal is culture in the broad sense of the word.

Now students know little about Russian business people, the largest figures in Russia's economic life as was noted above. And the development of a business culture in modern Russia is impossible without studying the history of domestic entrepreneurship and industry.

Now Russia continues to support its economy mainly due to the export of oil and gas. Our students are well aware of this. But do they know that the oil industry in Russia was founded by Vasily Alexandrovich Kokorev? He built an oil refinery in Surukhani in 1857 and later Kokorev established the Baku Oil Society. This business has taken such a pace that Russia had 51\% of all world oil production by the end of the century. Kokorev did not sell crude oil, but a highly refined oil product - kerosene at the same time. It should be noted that this kerosene was much better than that produced at that time in America, and its price was significantly lower. Kokorev was called the «merchant candidate

Rubin Yu. B. Entrepreneurship Fundamentals. - M.: MFPU «Synergy». - 2016. - 464 p. 
for finance ministers» [15] in Moscow, because he was distinguished by his desire and ability to clearly define the state objective interests and act in the framework of these interests exclusively.

Now he would be the defender of domestic manufacturer, but he was solving pending economic issues at that time. Rather, he fought for the export of flour, than corn, he did everything and would become a producer of its own finished product that Russia stopped being a European raw material colony. Hiswork in Surukhani at an oil refinery caused not only the boost in technological progress in kerosene production, but also indicated ways to reduce its cost.

Vasily Alexandrovich reviled the Russian manufacturers, he fought with officials for the construction of railways to the commercial sea ports, which the country so needed. Peter Ionovich Gubonin was done a lot of work in terms of railway construction with another entrepreneur-nugget.

His clear civic position was traced not only in the observance of the economic interests of his native state. V. A. Kokorev considered serfdom a disgrace of his native country and fought for its abolition, promoting the idea of buying out serfs and giving them freedom by merging the entire Russian merchants' capital. The preservation of Russian cultural heritage was the entrepreneur Kokorev's achievement. A gallery was established by him accessible for public, where the paintings of Aivazovsky, Bryullov, Levitsky, Kiprensky and other talented artists were flaunted. Later this collection became the entire part of the Tretyakov Gallery and the Russian Museum.

V. A. Kokorev also excelled on the basis of oratory and journalism. He left behind a number of works, as Russian Truth. It is included the idea of preserving Russia identity, using its wealth for the Russian people benefit. «For state though it is time to stop wandering outside its own land, to stop the search for economic foundations outside of Russia and clog violent transplants ... native soil; it's time, it's time to return home and learn about your strength in your people ...», he wrote in his book «Economic Failures» [7].

Patriotism and high morality were the exclusive features of not only the entrepreneur Kokorev. Above we already mentioned Peter Ionovich Gubonin, who was a vivid example of a Russian nugget who had pulled himself out of the bottom and gained respect among his compatriots in the business community. Former fortress masons, who first opened his small «stone business» and received an order to build stone bridges for the Moscow-Kursk Railway, P.I. Gubonin made his contribution into almost every Russian industry: the Baltic, Ural, Gornozavodskaya, Oryol ways were paved; winemaking and resort business in Gurzuf were developed; polytechnic exhibitions were organized; a lot of technical schools and other culture centers were founded. The former serfdom received hereditary nobility by a royal decree - «in consideration of his desire to promote public benefit with his labor and commons». P. I. Guboninwas not embittered despite his difficult serf past, but observing his economic interests he devoted his life to work for his native country benefit.

There are examples of other Russian entrepreneurs who worked - really worked, developing industry in their native country, trade, and supported scientific and technological progress, strengthening Russian economic and strategic positions. Russian entrepreneurs viewed their business not only as commerce as noted above, but also a kind of mission, felt their responsibility to the entire Russian people. A researcher of the Moscow merchants Buryshkin P. A. noted that charity and collecting which they looked at as fulfilling some kind of over-assigned duty were unusually developed among Russian entrepreneurs [3].

There is a tendency now, that even the most insignificant charity eventsgarner media coverage. But such 'notable' donations have nothing in common with Russian traditions. Historian Klyuchevsky V.O. stressed that Russia perceived and appreciated only personal, direct charity from hand to hand, moreover, secretly, not only from a prying eye [6]. Savva Timofeevich Morozov makes a good example here. Even in case of his participating in any charity project he was reluctant to announce it in a newspaper. Moreover, he personally took part in the construction of a new hospital - it was not only donating money, but his own efforts in building process, equipment purchasing.

Other Russian philanthropists are also known in history: Alexei Bakhrushin, who acquires exhibits for the theater museum on his own money; Kozma Terentyevich Soldatenkov, who fully financed the construction of the largest medical institution in Moscow and made a huge collection of paintings and published textbooks and other books for many years at his own expense; Gavrila Gavrilovich Solodovnikov, who built the largest theater in Moscow at that time and bequeathed all his fortune to the development of Russian provincial schools and colleges. It is obvious that the Russian philanthropic entrepreneurs were united by two other qualities - modesty and selflessness. It was interesting that even abroad considered the Russian patronage a special phenomenon at that time, because they believed that even patronage should generate income. Thus, everyone began to believe that patronage is a very special phenomenon in Russian.

Political writer Yanin notes that Russian business elite was not interested only in making money, the task was to become more than only business people - «to become Creators, Makers of the great Russian Business ... And there could be only one way to turn into an Actor out of a Moneymaker, ...to step on the path of creation» and to associate themselves with the country and people living in it [15]. 
Thus, future entrepreneurs face not only the task of obtaining professional knowledge in the field of modern concepts of management and business formation, but also with the task of obtaining professional skills of entrepreneurship development vision in historical retrospect, which will allow them in the future to gain the skills of strategic and large-scale thinking [13].

\section{Conclusion}

On the one hand, modern entrepreneurs should continue the traditions of the Russian merchants and take care not only of their own enrichment, but also of their fatherland's economic and spiritual prosperity. On the other hand, the current situation always does not con- tribute to the entrepreneurial qualities manifestation only on the positive side.

Russian businessmen moral qualities of the 21st century: sociability, observation, quick wits, hard work, openness to innovations, faith in one's own strength, lack of template thinking, reasonable risk, own PR, desire «just not to be disturbed».

In modern economic conditions, every individual has equal opportunities to succeed in increasing wealth. Modern economy creates the most favorable conditions for entrepreneurship development [11]. But the best results are achieved by the one who is able to combine knowledge, business acumen and moral principles.

\section{References}

1. Bezobrazov, V. P. (1828-1889) Narodnoye khozyaystvo Rossii. Moskovskaya (tsentral'naya) promyshlennaya oblast [People's economy of Russia. Moscow (central) industrial region]. Researched by V. P. Bezobrazova. SPb., Vol. 3, 146 p. (In Russ.).

2. Buryshkin, P. A. (1990) Moskva Kupecheskaya [Merchant Moscow]. Moscow. Available at: https://www. litmir.me/br/?b=49147\&p=1 (accessed: 01.04.2020) (In Russ.).

3. Buryshkin, P. A. (2013) Istoriya Rossiyskogo kupechestva [History of the Russian merchants]. Moscow, Eksmo, 640 p.

4. Rubin, Yu. B. (2015) Predprinimatel'skoye obrazovaniye v Rossii i za rubezhom: istoriya, soderzhaniye, standarty, kachestvo: monografiya [Entrepreneurial education in Russia and abroad: history, content, standards, quality: monograph]. Moscow. MFPU "Synergy", 416 p.

5. Kaminka, A. I. (1910) Ocherki torgovogo prava [Essays on the trade law]. Petersburg: Legal book, «law», $447 \mathrm{p}$.

6. Klyuchesvkiy, V. O. (1856) Kurs russkoy istorii [Course of Russian History]. Available at: https:// docviewer.yandex.ru/view/739055608/? * *xzDqUoljjZGh4M0XqoS84Dn4Pjp7InVybCI6Imh0dHA6Ly9wc3RndS5ydS9kb3dubG9hZC9rdXJzLnBkZiIsInRpdGxlIjoia3Vycy5wZGYiLCJ1aWQiOiI3MzkwNTU2MDgiLCJ5dSI6Ijc0MTc1NjE3ODE1NDAwNjAxNTUiLCJub2lmcmFtZSI6dHJ1ZSwidHMiOjE1NDI0ODQ4NDM2NjUsInNlcnBQYXJhbXMiOiJsYW5nPXJ1Jm5hbWU9a3Vycy5wZGYmdG09MTU0MjQ4NDgzNCZ0bGQ9cnUmdGV4dD01RDA1OTIuJUQwJTIFLiVEMCU5QSVEMCVCQiVEMSU4RSVEMSU4NyVEMCVCNSVEMCVCMIVEMSU4MSVEMCVCQSVEMCVCOCVEMCVCOSUyMCVEMCVCQSVEMSU4MYVEMSU4MCVEMSU4MSUyMCVEMSU4MCVEMSU4MyVEMSU4MSVEMSU4MSVEMCVCQSVEMCVCRSVEMCVCOSUYMCVEMCVCOCVEMSU4MSVEMSU4MiVEMCVCRSVEMSU4MCVEMCVCOCVEMCVCOCZ1 cmw9aHR0cCUzQSUyRiUyRnBzdGd1LnJ1JTJGZG93bmxvYWQ1MkZrdXJzLnBkZiZscj0yMTMmbWltZT1wZGYmbDEwbj1ydSZzaWduPTkzYWNjYzBjOWUwZmUxMWFhNzcxNGQ0MjhmNGMzMTBiJmtl eW5vPTAifQ\%3D\%3D\&lang=ru (accessed: 02.04.2020). (In Russ.)

7. Kokorev, V. A. (2005) Ekonomicheskiye provaly [Economic Failures]. Moscow: Society of merchants and industrialists of Russia, $336 \mathrm{p}$.

8. Mushtuk, O. Z. (2001) Obshchestvenno-politicheskaya i sotsial'no-kul'turnaya sreda biznesa v Rossii [Socio-political and socio-cultural environment of business in Russia]. Moscow, $140 \mathrm{p}$.

9. Petrazhitsky, L. I. (1911) Aktsii. Birzhevaya igra i teoriya ekonomicheskikh krizisov. Ob aktsionernom dele i tipicheskikh oshibkakh pri otsenke shansov neizvestnoy pribyli [Stocks. Stock market game and the theory of economic crises. On joint stock business and typical mistakes in assessing the chances of unknown profits]. Vol. 1. St. Petersburg : M. Merkushev's printing house, $319 \mathrm{p}$.

10. Ryabushinsky, V. P. (2010) Staroobryadchestvo i russkoye religioznoye chuvstvo; Russkiy khozyain; Stat'i ob ikone. [Old Believers and Russian religious feeling; Russian host; Articles about the icon]. Moscow, Bridges of Culture, $452 \mathrm{p}$.

11. Sizova, Yu. S. (2020) [Main milestones and features of entrepreneurship development]. Ekonomika i biznes: teoriya i praktika [Economics and business: theory and practice]. Vol. 5-2 (63), pp. 176-179. (In Russ.).

12. Sizova, Yu. S. (2019) [Modern entrepreneur in the VUCA world - advantages and difficulties]. Ekonomika i biznes: teoriya i praktika [Economics and business: theory and practice]. Vol. 8, pp. 145-150. (In Russ.).

13. Torskaya, A. N. (2019) [History of Russian entrepreneurship in the establishment of Russian management thought]. Problemy upravleniya sotsial'no-ekonomicheskimi sistemami: teoriya i praktika. Materialy VII Mezh- 
dunarodnoy nauchno-prakticheskoy konferentsii [Problems of management of socio-economic systems: theory and practice. Materials of the VII International Scientific and Practical Conference]. Pp. 103-107. (In Russ.).

14. Trifonova, V. V. (2017) [Features of teaching the history of Russian entrepreneurship in the framework of the competence-based approach]. Aktual'nyye problemy gumanitarnykh i sotsial'no-ekonomicheskikh nauk [Actual problems of the humanities and socio-economic sciences]. Vol. 11, No. S2, pp. 79-81. (In Russ.).

15. Yanin, I. T. (1999) Kul'tura protiv krizisa, ili Iskusstvo zhit'v Rossii [Culture Against Crisis, or The Art of Living in Russia]. Kaliningrad: Amber Story, 192 p.

\section{Information about the authors:}

Andrei Borisovitch Ilin, Ph. D in Economics, Associate Professor of the Department of Innovative Enterpreneurship, Bauman Moscow State Technical University, Moscow, Russia

ORCID ID: 0000-0002-4055-1814, Researcher ID: M-5928-2016

e-mail: ilandeducation@yandex.ru

Yulia Sergeevna Sizova, Ph.D in Economics, Associate Professor of Humanitarian Training Centre, Plekhanov Russian University of Economics, Moscow, Russia

ORCID ID: 0000-002-7760-6436

e-mail: Sizova.YS@rea.ru, ju-si@mail.ru

The paper was submitted:10.04.2020

Accepted for publication: 19.08.2020.

The authors have read and approved the final manuscript.

\section{Информация об авторах:}

Андрей Борисович Ильин, кандидат экономических наук, доцент кафедры инновационного предпринимательства, Московский государственный технический университет имени Н.Э. Баумана (национальный исследовательский университет), Москва, Россия

ORCID ID: 0000-0002-4055-1814, Researcher ID: M-5928-2016

e-mail: ilandeducation@yandex.ru

Юлия Сергеевна Сизова, кандидат экономических наук, доцент Центра гуманитарной подготовки, Российский экономический университет имени. Г. В. Плеханова, Москва, Россия

ORCID ID: 0000-002-7760-6436

e-mail: Sizova.YS@rea.ru, ju-si@mail.ru

Статья поступила в редакцию:10.04.2020; принята в печать: 19.08.2020.

Авторы прочитали и одобрили окончательный вариант рукописи. 